\title{
New Measurement System for Sustainability - MNB's Sustainability Report and Index
}

\author{
Róbert Hausmann *, Ákos Szalai * \\ Central Bank of Hungary [Magyar Nemzeti Bank; MNB], Budapest, Hungary. \\ * Correspondence: hausmannr@mnb.hu; szalaia@mnb.hu
}

\begin{abstract}
Our study explains why it is important to implement the aspects of sustainability in order to successfully converge and break out of the trap of medium development, and presents the main findings of the MNB Sustainability Report and Index based on a self-developed quantification-purpose methodology. The socio-economic system of a country is considered sustainable if its environmental, social, financial and real economy resources are used in a sustainable way to achieve and maintain longterm prosperity. The MNB's Sustainability Index ranks Hungary 15th among the $27 \mathrm{EU}$ member states in 2021, which is slightly better than the average ranking of the Visegrád countries, but slightly behind the EU average. There is room for improvement in all four priority areas, with the identification of the greatest scope for convergence in the financial and social sustainability dimensions. In line with the frameworks of international organisations (UN, OECD) with a strong track record in sustainability, the MNB report helps to identify key areas of potential sustainability strengths and reserves, thus supporting, on the one hand, long-term, strategic policy-making, specialised research in the field of sustainability and, on the other hand, sustainable convergence.
\end{abstract}

Keywords: sustainability; sustainable convergence; competitiveness; structural reforms

\section{Introduction}

Although the Covid-19 pandemic is still ongoing worldwide, it is clear that a very different economic and social order is emerging than one before the pandemic. In addition to the unprecedented period global economy and the world's population have been experiencing since March 2020 - including the victims of the virus and challenges such as the complete shutdown of certain economic segments (e.g. tourism), the disruptions of supply chains, or in many cases the transformation of homes from exclusive living space to multifunctional living

\section{Citation:}

Hausmann, R., \& Szalai, Á. (2021). A new measurement system for sustainability - the Sustainability Report and Index of the MNB. Prosperitas, 8(2), 3.

https://doi.org/10.31570/prosp_2021 -0003

\begin{tabular}{|c|c|}
\hline \multicolumn{2}{|l|}{ History: } \\
\hline Received: & 24 Nov 2021 \\
\hline Last Revised: & 25 Nov 2021 \\
\hline Accepted: & 26 Nov 2021 \\
\hline Published: & 6 Dec 2021 \\
\hline
\end{tabular}

\section{Copyright:}

(c) 2021 by the authors. Submitted for possible open access publication under the terms and conditions of the Creative Commons Attribution (CC $\mathrm{BY}-\mathrm{NC}$ ) license. and working spaces - the preparation for the post-virus pandemic period also offers many opportunities.

The growing impacts of the pandemic and climate change have highlighted the need to make environmental resource conservation, social sustainability as well as knowledge- and technology-driven nation building increasingly measurable as a prerequisite for ensuring longterm sustainability. Guaranteeing long-term sustainability is essential to achieving and maintaining high living standards. This interconnectedness is supported, among others, by Chapter 6 of the World Happiness Report 2020, which examines the relationship between sustainable development and human well-being using the UN Sustainable Development Goals (SDGs) and Gallup's representative subjective individual well-being indicator (De Neve \& Sachs, 2020). In addition to this, the limitations of GDP per capita in measuring the sustainability and well-being of countries are discussed in Chapter 2.3. of the book edited by Virág and written by Spéder (2019) and entitled Measuring GDP - The origins of the problem, in which the author draws attention to the shortcomings of measuring pollution, depletion of natural resources, leisure and learning opportunities within the framework of GDP. For successful convergence in the 21 st century, the creation of the right economic and social structure is essential, along with digitalisation, green transition, changing consumer habits, regionalisation and ageing societies, with all playing an important role. But all of these need to be put at the service of economic growth and convergence, and should be addressed in a 
way that sustainability features as a connective tissue. In other words, maintaining macroeconomic, macro-financial and social balance becomes the goal without the exhaustion of future generations' resources.

History, such as the fall of the ancient Roman Empire, the impoverishment of Lebanon or the destruction of the Easter Island civilisation, shows that the lack of sustainability can lead to long-term socio-economic damage or even total disintegration. The resource-intensive nature of the ancient Roman Empire led to the destruction of a significant proportion of the forests on its territory and soil erosion as well as swamping and the spread of malaria. This resource-intensive and environmentally destructive operation was based on the continuous expansion of agricultural land, the extraction of wood raw materials for construction, the building of wooden warships and metal mining activities with a view to sustaining wars and providing logistical support (Grüll, 2013; Grüll, 2017). Another example of forest destruction is the case of the cedar forests of the Lebanese mountains, which, in addition to sustaining the Phoenician merchant-ship culture, were decimated by the shipbuilding of Egyptian pharaohs, Mesopotamian rulers and the constructions of Emperor Hadrian monarch of the Roman Empire. Most of the remaining wooded areas were destroyed by the construction of the Maronite and Druze settlements and, in later times, by invaders (Mikesell, 1969). The population of Easter Island has brought about the destruction of their own civilisation through over-exploiting resources (over-expansion of agricultural land, depletion of freshwater resources, extinction of food source species) (Múlt-kor, 2020). Based on the historical examples presented, ignoring environmental sustainability can lead to a loss of competitiveness of a territorial unit in the medium term, and to serious socio-economic disruption in the longer term.

The issue of sustainability has been addressed by international organisations since the second half of the 1960s, but the terms "sustainability" and "sustainable convergence" are not yet integral part of international (economic) political decision-making, economic thinking and everyday life. This is why it is necessary to develop a framework that determines economic and social convergence in the 21st century, for the purpose of quantifying the results achieved and for making such results suitable for providing feedback. The concept of sustainability was most influentially highlighted by the Club of Rome, founded in 1968, which in its 1972 report "The Limits to Growth" addressed the finite nature of environmental resources as a fact and pointed out that unconditional economic growth would lead to the depletion of resources (Meadows, Meadows, Randers, et al., 1972). The essence of sustainable development was also highlighted in the 1987 report of the United Nations' World Commission on Environment and Development (Brundtland Commission), according to which the resources of the present should be utilised without compromising the ability of future generations to meet their own needs, thereby ensuring the long-term welfare of the citizens of a country (UN, 1987).

There is a debate among economists on how exactly sustainability should be defined, but most of them agree that it should be treated holistically, i.e. the interplay between the economy, society and the environment should be addressed in the scope of a joint system (Hardi\&Barg, 1997; Dresner, 2002). Among Hungarian economists, Sándor Kopátsy is also a thinker on sustainability, who - together with many other perspective thinkers - sought to capture the long-term welfare of the Hungarian socio-economic system in his book T.E.T.T. The society of quality (2000) and in his volume New Economics - The Society of quality (2011). Sándor Kerekes (1998) defines sustainable development as meaning sustainable economic, ecological and social development and states that the concept can also be used in a narrower sense, limited to the environmental interpretation.

The Sustainability Report and Index, a tool of the Magyar Nemzeti Bank (MNB) that measures the sustainability of socio-economic systems, analyses in detail, and measures, the key factors of Hungary's long-term sustainable convergence in a European Union comparison. In light of the above, in a new publication entitled the MNB Sustainability Report, we have attempted to quantify the long-term sustainability and welfare potential of our country's socioeconomic model using a composite indicator based on a self-developed methodology. As a theoretical basis, we considered the book Long-term sustainable econo-mix (Virág ed., 2019), published by the Magyar Nemzeti Bank in 2019, which aimed to explore those global megatrends and problems that will shape our future the most. In the MNB's Sustainability Report and its Sustainability Index, which is part of the former, we have assessed the situation and prospects of long-term prosperity in Hungary in an EU comparison using an independent methodology for the first time in Hungarian economic literature and thus offer a tool filling in 
this research gap. In the following, we describe the methodology and results of our report as well as the conclusions that can be drawn from them.

\section{Literature review / Hypotheses}

The concept of sustainable development and convergence is a theory of growth that includes social, environmental and economic aspects. A review of the literature suggests that sustainability or sustainable convergence is based on three pillars: inclusive growth that includes social ascent and justice, the efficient use of natural resources in consideration of their renewability and real economy growth based on output and productivity growth that takes into account financial stability as well (Mensah, 2019). If these pillars are in balance and mutually reinforce each other, the long-term stability and sustainable development of a country will be achieved. The literature distinguishes between "weak" and "strong" sustainability. The two concepts are based on the different notions of natural and man-made social capital. "Weak" sustainability is the notion that the total stock of capital can be produced from any combination of the two different types of capital (natural and man-made), i.e. the two types of capital can be substituted for each other to some extent. The concept of "strong" sustainability, on the other hand, implies that the two types of capital are complementary and not substitutes for each other, i.e. both types of capital must be maintained to a certain extent in order to avoid upsetting their balance and thus sustainable socio-economic functioning (Daly, 1996).

The UN Sustainable Development Goals (SDGs) and the OECD Sustainable Development Framework (SDF) pragmatically translate the concept of sustainable convergence into international relations. Building on the reports of the Club of Rome and the Brundtland Commission as well as on the principles of sustainable convergence set out earlier, the UN created a programme named Agenda 21 (Rio Declaration) in 1992 to mainstream sustainability into national and global decision-making. To monitor the implementation of this declaration, the UN Commission on Sustainable Development (UN, 1992) was established. In 1997 (and again in 2002), the progress in implementing Agenda 21 was reviewed, and in 2000 it was supplemented by the formulation of the 8 Millennium Development Goals (MDGs) to be achieved by 2015, including the attainment of environmental sustainability (UN, 2000). In 2012, 20 years after the Rio UN Summit, 180 countries around the world reaffirmed the content of Agenda 21, and in 2015, with the expiry of the Millennium Development Goals, another 17 Sustainable Development Goals (SDGs) were set to be achieved by 2030 (UN, 2012). The new targets include good health, quality education, reducing social inequalities and ensuring affordable and clean energy sources. In addition to the United Nations, the OECD has also addressed the concept of sustainable development in a number of analyses and has developed a framework for the mainstreaming and institutionalisation of sustainability in national decision-making. The OECD framework emphasises the joint enforcement of economic, environmental and social considerations and the importance of sustainability in the implementation of long-term planning against short-term political goals (OECD, 2007).

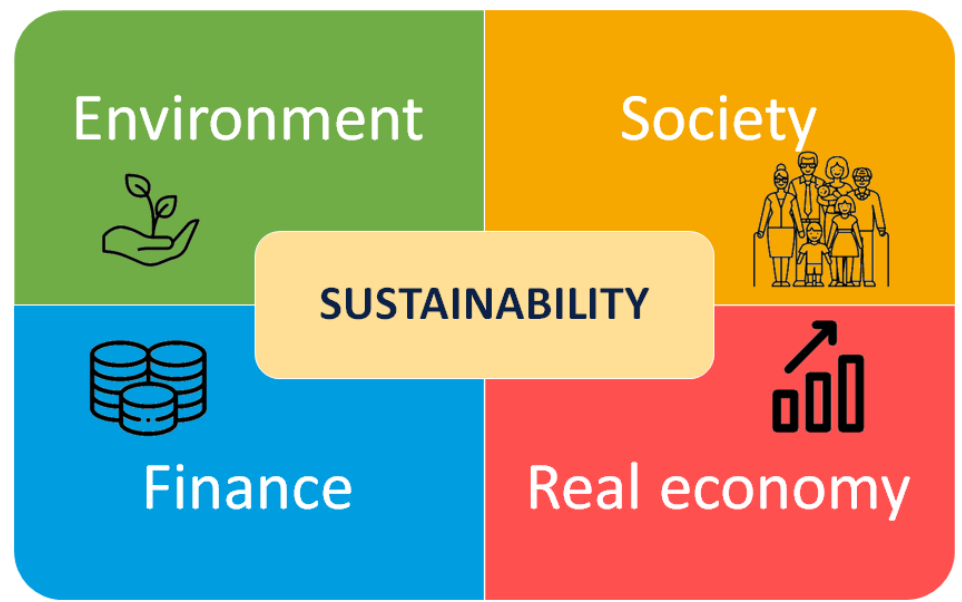

Figure 1. Four pillars of a sustainable social and economic model. Source: Magyar Nemzeti Bank 
According to the definition of the Magyar Nemzeti Bank, a country's socio-economic system is sustainable if its environmental, social, financial and real economy resources are used sustainably to achieve and maintain long-term prosperity (Figure 1). To develop our approach, we have taken into account the basic principles of international organisations (UN, OECD) and the literature on sustainability. The purpose of the Sustainability Report is to assess and make measurable the long-term sustainable key factors of Hungary's convergence, which are less focal in central banks' traditional macroeconomic and financial analyses despite the fact that they have a determinant role in the lasting sustenance of economic and social welfare and successful convergence. Contrary to the MNB's publications on competitiveness, the Magyar Nemzeti Bank's Sustainability Report intended to capture the long-term sustainability of the current national economy and social models rather than the performance achievable by individual countries in the medium run (MNB, 2021).

Two interrelated hypotheses were formulated for the Sustainability Report, which were tested through a comprehensive empirical analysis:

1. In the medium term, balance and growth and in the long term, as well as sustainability and competitiveness go hand in hand to ensure a country's efficient socio-economic performance (Figure 2). As result of the economic and competitiveness reforms of the last decade, Hungary has been on a balanced convergence path since 2013 and the turnaround in competitiveness has also started (Matolcsy, 2020a). Following the achievement of macroeconomic and financial balance, the Hungarian economy, between 2013 and 2019, grew by two percentage points faster (3.8 percent) than the average real economy growth rate in the European Union (1.8 percent). However, it is only possible to further sustain and increase the growth surplus in the long term by ensuring a balance between environmental, human, financial and real economy capital, i.e. sustainability. Such recognition can also contribute to the full realisation of the turnaround in competitiveness that is already underway, the integral parts of which are increasing labour productivity, structural reforms and a shift from an investment-led to a technology and innovation-led growth model.

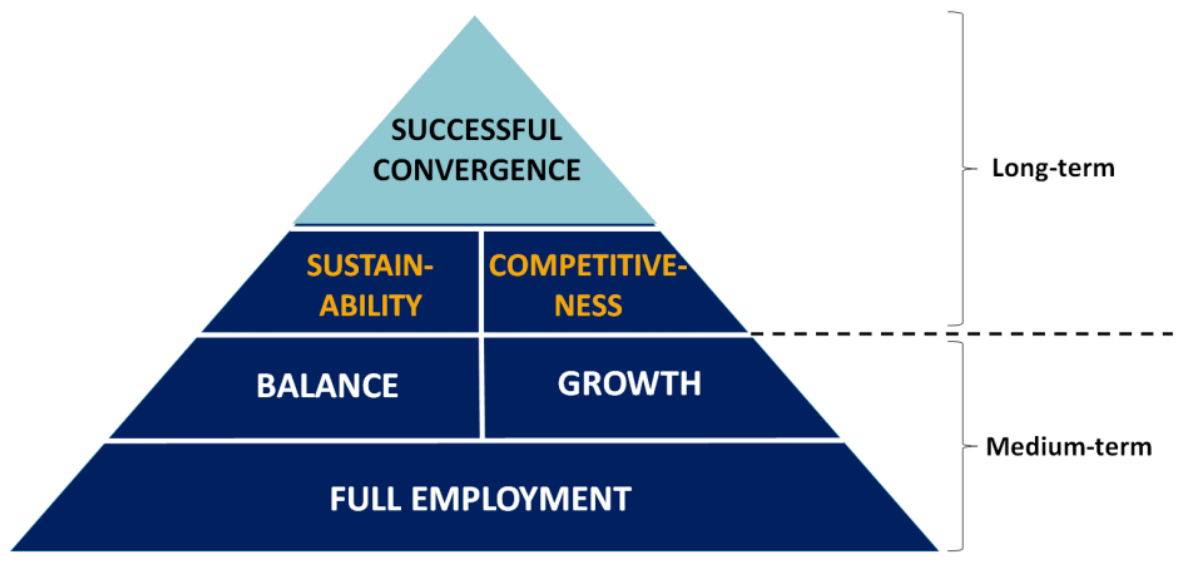

Figure 2. Theoretical elements of sustainable convergence. Source: Magyar Nemzeti Bank.

2. There is a strong correlation between the relative development and sustainability of countries. In preparing the Sustainability Report, we previously assumed that countries with a higher gross domestic product per capita would have a more sustainable socio-economic system. Two contributions justified the testing of this hypothesis: on the one hand, the MNB's 2020 Competitiveness Report, which showed a strong correlation (R2=0.78) between the level of development and competitiveness of EU Member States (MNB, 2020). Of course, this link is not equally strong in all dimensions. The real economy and social sustainability of more developed countries is strong, while they do not perform much better than less developed countries in terms of environmental sustainability. On the other hand, the support attested by international literature to the link between economic development and sustainability is also empirical. In their study, Mohan, 
Thyagarajan and Muller (2020) use the environmental Kuznets curve to illustrate the relationship between natural resource use, an important element of sustainability, and GDP per capita. According to the environmental Kuznets curve, as long as a country's GDP per capita is low, its emissions harmful to the environment are also low. As the level of development increases, the environmental damage and its financial value increases, and then starts to decrease after a certain level of development is reached. This process creates an inverted $U$ shape. The three authors argue that the use of natural resources should not be measured in terms of the amount of physical emissions in tonne, but rather in terms of the financial cost of the damage caused. Methodologically, this is done by subtracting the cost of estimated environmental damage from a country's gross output to produce an adjusted GDP figure. GDP growth, corrected for the costs of environmental damage, has been much lower than traditional GDP growth, especially in the case of large emerging economies (e.g. China or India), when looking at their GDP growth between 1998 and 2018.

\section{Methodology}

The MNB's Sustainability Report assesses and ranks Hungary's sustainable convergence position in the European Union relying on 108 - almost solely objective indicators (Figure 3). 98 percent of the indicators used can be considered objective indicators, i.e. they are based on numerical statistics or the results of an authentic, sufficiently focused survey. In addition to textual evaluation, the framework developed by the Magyar Nemzeti Bank also facilitates the quantification of the results and provides feedback. As part of the framework 108 factual indicators in four main areas are analysed and aggregated at different levels in order to support transparent evaluation. For producing the indicators examined, we analysed the performance of the $27 \mathrm{EU}$ Member States, the arithmetic average of the EU Member States' performances and the averages of our narrower region, the competitor Visegrád countries (the V3).

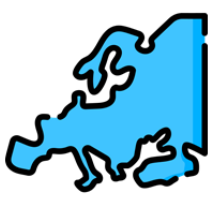

27 countries

EU members

Benchmark: EU, V3

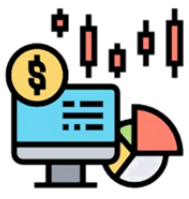

108 indicators

27 analysed topics

4 pillars

98 percent objective

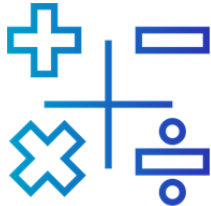

$$
\begin{gathered}
\text { Self-developed } \\
\text { methodology } \\
\text { Further development of the } \\
\text { distance to frontier } \\
\text { methodology taking into } \\
\text { account standard deviation }
\end{gathered}
$$

Based on MNB Banking System Competitiveness Index (2017)

Figure 3. Structure and methodological features of MNB Sustainability Report. Source: Magyar Nemzeti Bank

From the 108 indicators, we have created the MNB Sustainability Index using an independently developed methodology. For the ranking of the performance of individual countries, the MNB created a composite index relying on its self-developed methodology applied in the scope of the MNB Banking System Competitiveness Index (Asztalos, Horváth, Krakovsky, et al., 2017). In proportion to their performance, countries are allocated scores of $0-100$, with the best performing country scoring 100 points. The score of other countries depend on how much they deviate from the optimal value of the best performing country. When calculating the score, only those countries with at least 4 standard deviations from the best score receive zero point. The main advantages of the methodology include the following: the data are not to follow a normal distribution, the optimal value of the indicator can be freely 
chosen, it is not necessary to rely on a fixed statistical indicator, and the calculation of the score tracks the variance in the values of the countries included in the sample. The overall country score of the MNB Sustainability Index is the average of the 4 pillars that constitute the index, with each weighting 25 percent; furthermore, within the individual pillars the sub-pillars were also included with identical weight. This arrangement ensures that in a top-down approach the distinct areas represent the same weight. However, to this end, the weights of the individual indicators may marginally vary (MNB, 2021).

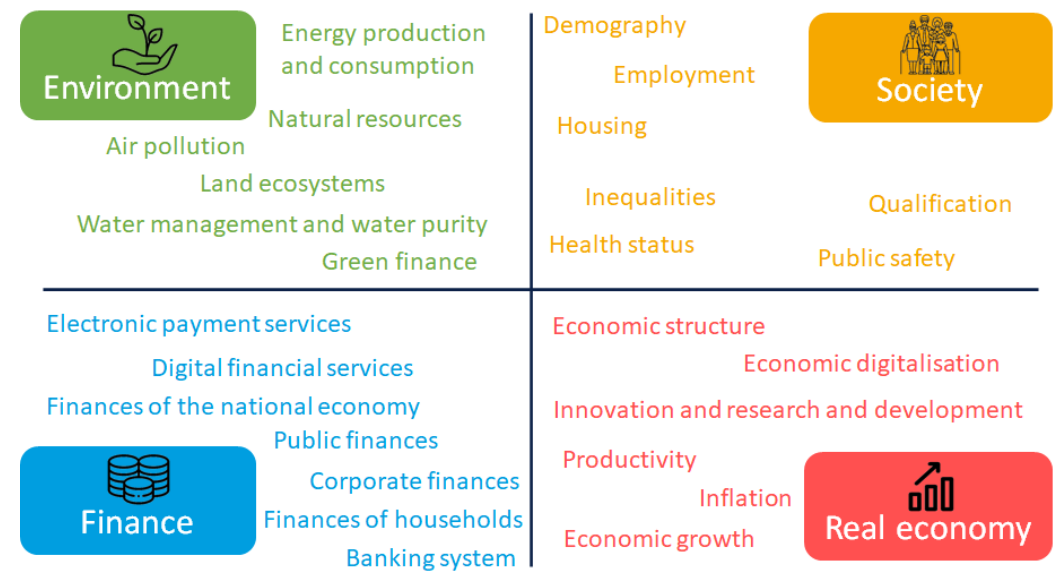

Figure 4. Pillars and sub-pillars of the MNB Sustainability Report. Source: Magyar Nemzeti Bank

The Sustainability Index examines the factors that determine the long-term welfare of nations based on four pillars: environmental, social, financial and real economy considerations (Figure 4). The MNB's Sustainability Report has defined these four main areas based on the UN conceptual framework for sustainable development and our own definition. When developing the set of indicators in our report, we have taken into account the methodology of international sustainability rankings. The role of environmental considerations in sustainability is indisputable, because it is only ensuring the reproduction of natural resources that can guarantee the welfare of future generations, which requires pollution and energy consumption reduction. In addition, strengthening the green economy - and particularly decreasing air pollution - also improves people's health. Furthermore, sustainability can only be achieved with a sufficient quantity and quality (healthy and skilled) of human capital, coupled with public security, sufficient income and housing for a carefree subsistence and family life. Accordingly, in the scope of the MNB's Sustainability Report, we examine social aspects. In fact, maintaining economic competitiveness of Hungary in the long run requires accessible financial capital in sufficient volume and sound structure, the status of which is examined by the financial sustainability indicators. However, sustainable convergence is unfeasible without stable and persistently improving economic fundaments, or an innovative and modern economic structure. Thus, accordingly, we also analyse the sustainability of economic growth as the fourth main area in the Sustainability Index (MNB, 2021).

In the environmental sustainability pillar we examined environmentally friendly and efficient energy consumption as well as the state of the green and circular economy. The creation of a separate environmental pillar was prompted by the development of environmental economics, a branch of economics pioneered by Nobel Prize-winning economist William Nordhaus, who was awarded the Nobel Prize in 2018 for his work on integrating climate change into long-term macroeconomic models. Nordhaus (1992, 2017) linked the environmental impacts of climate change to economic growth in his so-called DICE model (Dynamic Integrated Model of Climate and the Economy), which, despite its perception as simplistic by many, is the starting point for most environmental economic modelling.

In Europe, the Magyar Nemzeti Bank was the first bank to have a legal mandate to promote environmental sustainability. Even prior to this, the MNB paid special attention to environmental sustainability, and as part of its efforts to this end it was one of the first ones to create a dedicated green bond portfolio in foreign exchange reserves, and announced its Green Programme in early 2019 (MNB, 2019 a; b). Following the publication of the Green Monetary Policy Toolkit Strategy in July 2021, the MNB's Green Home Programme was 
quickly launched to help renew the domestic housing stock while significantly improving the energy efficiency of real estates. The MNB's Sustainability Report assessed the area in six sub-pillars using 24 indicators. In addition to energy production and use describing the supply and demand side of energy management, the maturity of the green and circular economy was also quantified by analysing greenhouse gas emissions, the sustainability of land ecosystems, waste management and water management. As the carbon-neutral economic transition requires significant green investment, we complemented our analysis with an examination of the fundaments of green finances.

In addition to the quantity and quality of labour force available in the long run, in the scope of the social sustainability pillar, we assessed the conditions of safe and sustainable family life. The issue of social sustainability is closely related to economic sustainability, which has been highlighted by various directions of the endogenous growth theory. As early as after the Second World War, Jánossy (1966) highlighted the role of human capital in the recovery process and in ensuring economic development, which was followed by the empirical results of Mankiw and his colleagues (1992), and in a similar fashion Lucas (1988) placed the acquisition of human capital at the centre of his model (Palotai, Virág, ed., 2016). The MNB's Sustainability Report examined at the area in eight sub-pillars, based on 32 indicators. Successful convergence cannot be achieved with a shrinking population, so the monitoring of demographic trends was considered crucial. Labour market, education and health issues are closely interlinked: full employment, the highest attainable skills and good health are the most beneficial factors from an individual's viewpoint and the perspective of sustainability, and therefore all these dimensions are included in our analysis. Fair incomes and financial welfare are part of social sustainability, so we take into account the evolution of real wages and consumption as well as housing conditions, income and wealth inequalities and public safety.

In the financial sustainability pillar, we examined the long-term sustainable financial development of the financial intermediary system, of the national government, of the national economy as well as of corporations and households along with the penetration of digital financial solutions. The inclusion of this pillar in our sustainability analysis was justified, in a narrower sense, by the mandate of the Law on the Magyar Nemzeti Bank (Government of Hungary, 2013) empowering the MNB to guarantee financial stability, and in a broader sense, by the effectiveness of micro- and macro-prudential policy (Restoy, 2020), which is concentrated in the hands of central banks. We assessed the area in seven sub-pillars, based on 29 indicators. Long-term maintenance of welfare also calls for financial stability, easily accessible, diversified and cheap funds as well as financial solutions that keep pace with technology. In addition to the cost-effectiveness of the banking system, we looked at the financial situation of households and businesses, public finances and the national economy as well as the sustainability of the digitalisation of the financial system and electronic payment services.

Finally, sustainable growth is essential for the convergence of our development and living standards, which calls for - in addition to macroeconomic balance - a more productive, innovative and digitalised economic system. Solid macroeconomic fundaments serve as precondition for a sustainable economic model. We therefore focused our analysis of real economy factors on increasing productivity and the level of digitalisation, in addition to analysing economic growth and inflation resulting from the price stability mandate of the MNB. The theoretical background of analysing productivity and digitalisation factors has been supported by the discipline of innovation economics: the discipline is based on the work of Joseph Schumpeter, who argued in his work The Theory of Economic Development (1934) that the basis of technological progress and economic growth is innovation (creative destruction). The development of a sustainable economic model also requires the application of digital solutions and technologies as well as the structural transformation of the economy, so the sustainability of these areas has been analysed in separate sub-pillars. We examined the area in six sub-pillars, based on 23 indicators.

\section{Results}

It is important to visualize the results of the study, and it is equally important to include in this section a brief analysis of the paper's data as well as a discussion concerning the reliability and validity of the data used (if applicable). 


\subsection{Numerical results featured in the MNB Sustainability Index}

Hungary ranks 15th among the $27 \mathrm{EU}$ Member States, slightly above the average of the other Visegrád countries (Figure 5). Based on the aggregation of the indicators used for the MNB Sustainability Index, Hungary scored 51.8 points, which was slightly higher than the average of the $\mathrm{V} 3$ countries (51.1) and only 2.1 points below the EU average (53.9). Sweden, Denmark and Finland scored the highest in the MNB Sustainability Index, while Cyprus, Greece and Romania scored the lowest. Among the V3 countries, only the Czech Republic (12th) scored above the EU average, with Slovakia and Poland lagging behind, ranking 21st and 22nd, respectively. Eight of the top ten places in the sustainability ranking were taken by developed European countries, but two converging countries (Estonia, Slovenia) managed to catch up to the leading countries. Meanwhile, Mediterranean countries and Central and Eastern European countries were likely to be in the middle or at the bottom of the ranking (MNB, 2021).

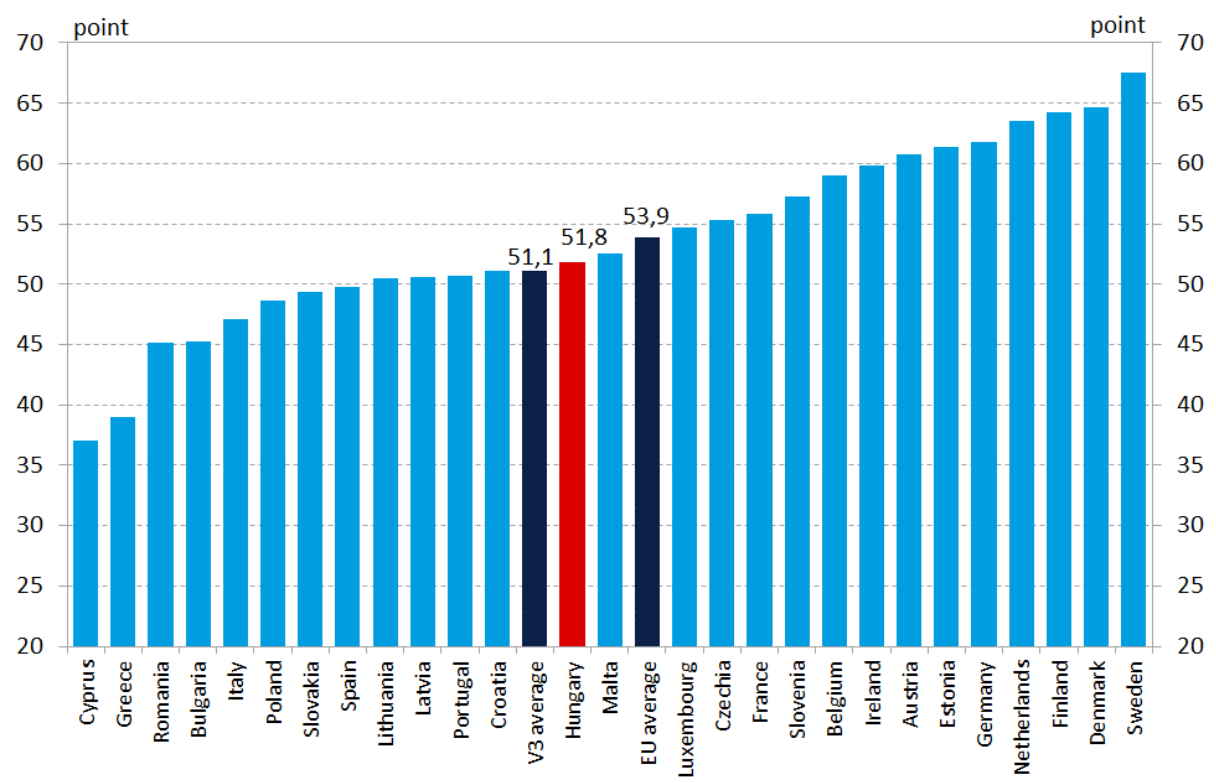

Figure 5. Aggregated result of the MNB Sustainability Index (2021). Source: Magyar Nemzeti Bank.

Note: The scale ranges from 0 to 100 points, with 100 being the best value.

Within the four areas, Hungary achieved the most favourable ranking in the field of environmental sustainability, ranking 11th with 48.7 points: Hungary's overall performance in indicators on energy production and use, the use of natural resources and green finances is better than the average of the Visegrád region and the EU. However, among the four pillars of the MNB Sustainability Index, Hungary achieved the lowest score in the environmental sustainability pillar. The sustainability of Hungary's economic growth (16th, 43.9 points) exceeds the average performance of the other Visegrád countries, but is slightly below the EU average. Among the countries surveyed this area shows the highest standard deviation concerning the four pillars. In the social sustainability dimension (18th, 58.7 points) and the financial sustainability dimension (21st, 55.9 points), Hungary performs below the average of the EU and the Visegrád competitor countries (Figure 6). Detailed results in the sub-pillars of the MNB Sustainability Index are presented in Figure 1 of the Appendix. 


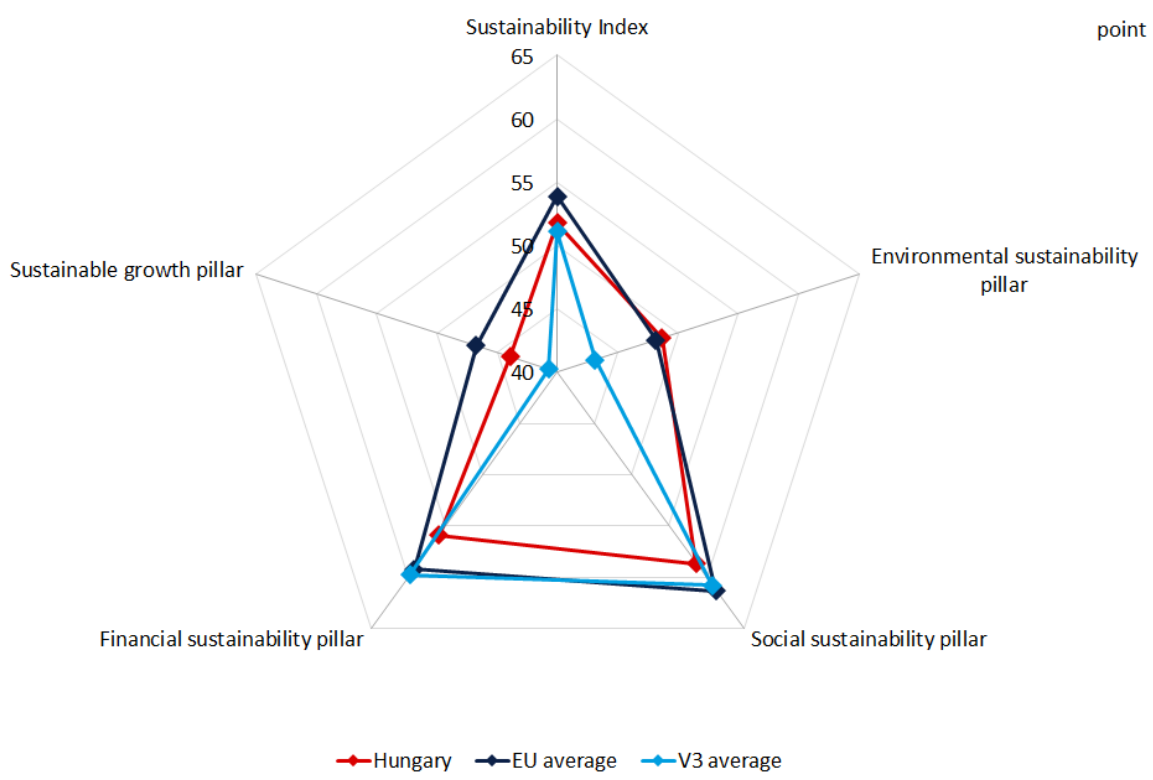

Figure 6. Results of the MNB Sustainability Index and its 4 pillars. Source: Magyar Nemzeti Bank

Note: The scale ranges from 0 to 100 points, with 100 being the best value.

\subsection{Hungary's strengths of sustainability}

In terms of environmental sustainability, Hungary's performance is also better than the EU and Visegrád averages in terms of energy production and use, the use of our natural resources and the development of green finances. In Hungary, energy use per unit of economic output has improved by around twenty percent over the last 10 years, but it is still 1.7 times above the EU average. Household electricity and natural gas prices have fallen below the Visegrád and EU averages as a result of a series of cuts and the fixing of official energy prices at low levels. Hungary is also among the EU leaders in reducing greenhouse gas emissions, with a 32 percent reduction in emissions of greenhouse gases compared to 1990, as compared to 30 percent in the V3 countries and 21 percent in the EU. As an indication of the maturity of green finances, 2020 saw Hungary ranking the second in terms of the highest share of green bonds in the total of government bonds issued (6.2 percent).

Hungary ranks among the EU leaders in public safety and is ahead of the EU and Visegrád averages also in economic growth. Public confidence and security are strengthened by the fact that the number of thefts and voluntary manslaughters in Hungary is lower than the EU average. Both wealth and income inequalities as well as the proportion of people at risk of poverty and social exclusion are below the EU average in Hungary. In addition to these, stable macroeconomic and financial fundamentals will help Hungary to continue its sustainable convergence process. Average growth of the economy (2.1 percent) was the ninth highest in Hungary between 2010 and 2020 in the European Union, which exceeded the EU average ( 0.9 percent), but slightly lagged behind the $\mathrm{V} 3$ average (2.4 percent). The fact that Hungary had the second highest investment rate (27.2 percent) in the European Union in 2019 also contributed to successful economic growth. Maintaining high levels of investment remains an important task for sustainable convergence, which provides a stable basis for the economy's long-term growth capacity through capital accumulation (Hausmann, 2021).

\subsection{Growth and welfare reserves in the sustainability of Hungary}

The emergence of a modern and efficient financial ecosystem is likely to be facilitated by a reduction in the operating costs of the banking system, which could be supported by the spread of digital finances and electronic payment services. The domestic banking system is the second most expensive in the European Union, with banks' operating costs per assets reaching 2.4 percent. This is higher than both the $\mathrm{V} 3$ average (1.7 percent) and the average of the 27 EU Member States (1.6 percent). Increasing the share of online banking (58 percent) 
and borrowing (less than 1 percent) could play a role in reducing operating costs. Although electronic payments are constantly evolving and payment solutions involving bank cards and mobile applications are on the rise, the number of card purchases per capita (102) in 2019 was below both the regional (140) and the EU average (139). The growth of fintech solutions operating within a regulated framework can also help minimise the cost of access to capital, a key element of financial sustainability in the 21 st century.

Successful convergence also requires a transition to an innovation-driven economic model as well as the widespread adoption of digital solutions and a shift in the economic structure towards knowledge-intensive activities. Labour productivity in Hungary grew by an average of 3.5 percent per year between 2017 and 2019, which is above the EU average (0.8 percent). Also, the efficiency gap between large companies and SMEs narrowed. Nonetheless, the convergence of SMEs to large companies in terms of productivity remains an important growth reserve for Hungary. Strengthening business innovation can contribute to convergence and thus to making the business sector more sustainable. This could be achieved by increasing the R\&D spending of the current level of 1.5 percent of GDP and by increasing the number of patents registered. The penetration of digital solutions such as business management software, big data, cloud solutions and artificial intelligence (11 percent) among Hungarian SMEs is still the second lowest in the EU. The widespread uptake of business digitalisation is also expected to contribute to Hungary's transition to a more knowledge-intensive economic structure, thereby supporting the maintenance of the growth surplus of the Hungarian economy relative to the EU.

Hungary's environmental sustainability can be strengthened through green investments, regulatory reforms and the spread of green finances. Although Hungary performs well in the EU in the area of environmental sustainability, its score in this pillar is the second lowest of the four pillars of the Sustainability Index (following the real economy dimension). The energy intensity of the Hungarian economy is 1.7 times the EU average, which means that Hungary uses 1.7 times more energy per unit of economic output than the EU. This relatively high energy intensity implies a high energy demand, which results in a high net energy import ratio (60 percent on average in the period of 2015-19) due to the low share of renewables in total energy use (12.6 percent). The expansion of environmentally friendly energy capacity can be achieved mainly by increasing solar cell and geothermal energy capacity, while maintaining nuclear energy capacity. The more widespread use of these solutions would also reduce Hungary's energy dependence and thus increase its energy security. In addition to the already mature green government securities market, the financing of green investments can be facilitated by the emerging domestic green corporate bond market (1.4 percent of all corporate bonds were considered green in 2020) and the spread of green lending products, which is actively supported by the Magyar Nemzeti Bank through its Green programme.

Hungary's social sustainability can be further strengthened by expanding its highly skilled and healthy workforce and making housing more accessible. Housing prices relative to income are the fourth highest in Budapest among EU capitals, and the proportion of people living in severely inadequate housing conditions is also relatively high in Hungary. The development of the demographic turnaround, which began already in the 2010s, would greatly be facilitated by real estate prices and rents more in line with median incomes. Countries achieving sustainable prosperity build their economies on their intellectual capital, thus convergence, in terms of the share of young people pursuing education in sciences (12 percent) and equipped with at least basic digital skills (49 percent), to the EU average (18 and 56 percent, respectively) is essential for the sustainable convergence of Hungary. At the same time, a sustainable society can only be achieved if its citizens are physically and mentally healthy. The importance of this is highlighted by the fact that in Hungary the proportion of deaths from behavioural risks (51.1 percent) is the fourth highest in the EU, which could be improved with the help of, among other things, stronger prevention based on individual responsibility.

\section{Comparison with other sustainability rankings}

Hungary's ranking of 15th in the MNB Sustainability Index is in line with its performance in international sustainability rankings (Table 1). In the 2020 ranking of the UN Sustainable 
Development Report, Hungary was ranked 29th out of 166 countries and 19th out of the 27 EU Member States ranked. The primary purpose of the report of the UN is to measure social and environmental sustainability along Sustainable Development Goals defined by the organisation using 115 indicators, most of which are objective (Sachs, Schmidt-Traub, Kroll, et al., 2020). In another international ranking called the SolAbility Global Sustainability Competitiveness Index (GSCI), Hungary was ranked 24th out of 180 countries in 2020, which means the 18th place out of the $27 \mathrm{EU}$ Member States ranked. This is a comprehensive competitiveness ranking that uses 127 indicators across 5 pillars (natural capital, social capital, intellectual capital, governance efficiency and resource efficiency) with a focus on sustainability, and more than 90 percent of the indicators are objective indicators (SolAbility, 2020). The Sustainable Society Index (SSI) of Technische Hochschule Köln assesses the sustainability of countries in the social, environmental and economic welfare dimensions using 21 indicators, out of which 95 percent are objective. In the 2018 ranking, Hungary was the 22nd out of 154 countries and the 13th out of 27 EU Member States (TH Köln, 2018). The presentation of the results is special, because the Cologne-based institute publishes aggregated scores along the three dimensions, and allows users to decide on the weights to construct their own composite index. In the scope of our study, we weighted the social, environmental and economic dimensions equally. The planetary pressure-adjusted HDI (PHDI), a modified version of the UN's Human Development Index (HDI), adds two new indicators - carbon dioxide emission per capita and ecological footprint per capita - to the original four (life expectancy at birth, expected and average years of schooling and GNI per capita) indicators. Based on 2019 data, Hungary was ranked 16th out of 169 countries and 12th out of $27 \mathrm{EU}$ Member States according to the latter index complemented with planetary pressure (UN, 2019; MNB, 2021).

Table 1. Main sustainability indicators and structural features of the MNB's new Sustainability Index. Source: Magyar Nemzeti Bank

\begin{tabular}{|c|c|c|c|c|c|}
\hline & $\begin{array}{l}\text { Sustainable } \\
\text { Development } \\
\text { Goal Index }\end{array}$ & $\begin{array}{c}\text { Global Sustainable } \\
\text { Competitiveness Index }\end{array}$ & $\begin{array}{l}\text { Sustainable } \\
\text { Society Index }\end{array}$ & $\begin{array}{c}\text { Planetary } \\
\text { pressures- } \\
\text { adjusted } \\
\text { HDI } \\
\text { (PHDI) }\end{array}$ & $\begin{array}{c}\text { MNB } \\
\text { Sustainability } \\
\text { Index }\end{array}$ \\
\hline $\begin{array}{c}\text { Ranking of Hungary } \\
\text { among all countries } \\
\text { assessed }\end{array}$ & 29. & 24. & 22. & 16. & 15. \\
\hline $\begin{array}{c}\text { Ranking of Hungary } \\
\text { among the EU27 } \\
\text { countries }\end{array}$ & 19. & 18. & 13. & 12. & 15. \\
\hline $\begin{array}{c}\text { Number of all countries } \\
\text { assessed }\end{array}$ & 166 & 180 & 154 & 169 & 27 \\
\hline Number of indicators & 115 & 127 & 21 & 6 & 108 \\
\hline $\begin{array}{c}\text { Ratio of objective } \\
\text { indicators }\end{array}$ & $92 \%$ & $>90 \%$ & $95 \%$ & $100 \%$ & $98 \%$ \\
\hline Comprehensive? & $\checkmark$ & $\checkmark$ & $x$ & $x$ & $\checkmark$ \\
\hline Global? & $\checkmark$ & $\checkmark$ & $\checkmark$ & $\checkmark$ & $X^{*}$ \\
\hline Objective? & $\checkmark$ & $\checkmark$ & $\checkmark$ & $\checkmark$ & $\checkmark$ \\
\hline
\end{tabular}

Note: * means that the MNB Sustainability Report is a national rather than an international report, so it does not strive to be global. Source: Magyar Nemzeti Bank

While maintaining the balance and growth that proved successful in Hungary's economic policy in the 2010s, in the long run the combination of sustainability and competitiveness can contribute to breaking out of the trap of medium development and to successful convergence. The historical analysis of macroeconomic and financial indicators in the MNB Sustainability Report confirms that the successful crisis management and economic 
policy consolidation implemented in the early 2010s, i.e. comprehensive and far-reaching economic reforms, put and have kept the Hungarian economy on a path of balanced convergence since 2013. Structural reforms have an asymmetrical effect over time, in terms of their impact on economic growth: reforms involve sacrificies over the short run, while their advantages typically materialise over longer time horizon. , They have led to a balanced turnaround in the short term in Hungary supporting the growth turnaround in the medium and long term. In other words, everything that has contributed to the consolidation of public finances in the short term - including preventing a rise in and reducing the public debt ratio, balancing the market and the current account balance - has strengthened economic growth and the increase in employment in the longer term (Matolcsy, 2020a). However, once balance and growth have been achieved, a turnaround in the structure of the economy as well as in the economic and social competitiveness of Hungary is also needed. These are necessary in order to ensure sustainable convergence and to break out of the medium development trap through new competitiveness reforms capable of supporting the transition from the current extensive growth model to an intensive, technology and innovation-led model. In the 2021 MNB Sustainability Index, Hungary ranked 15th, which is better than its 18th place in the 2021 MNB Competitiveness Index and its 21st place in the 2020 development ranking among the 27 EU Member States. This development ranking is a ranking by the GDP per capita of each country at purchasing power parity. The positions achieved in these rankings and their correlation with each other underline the need to strengthen the sustainability of the domestic socio-economic system while strengthening competitiveness, which will support the unlocking of growth potential in Hungary's relative level of development and thus contribute to Hungary's sustainable convergence. Therefore, in the MNB Sustainability Report 2021, we proved our Hypothesis 1 , namely that a country can only be competitive if it is sustainable in terms of its socio-economic development, and vice versa.

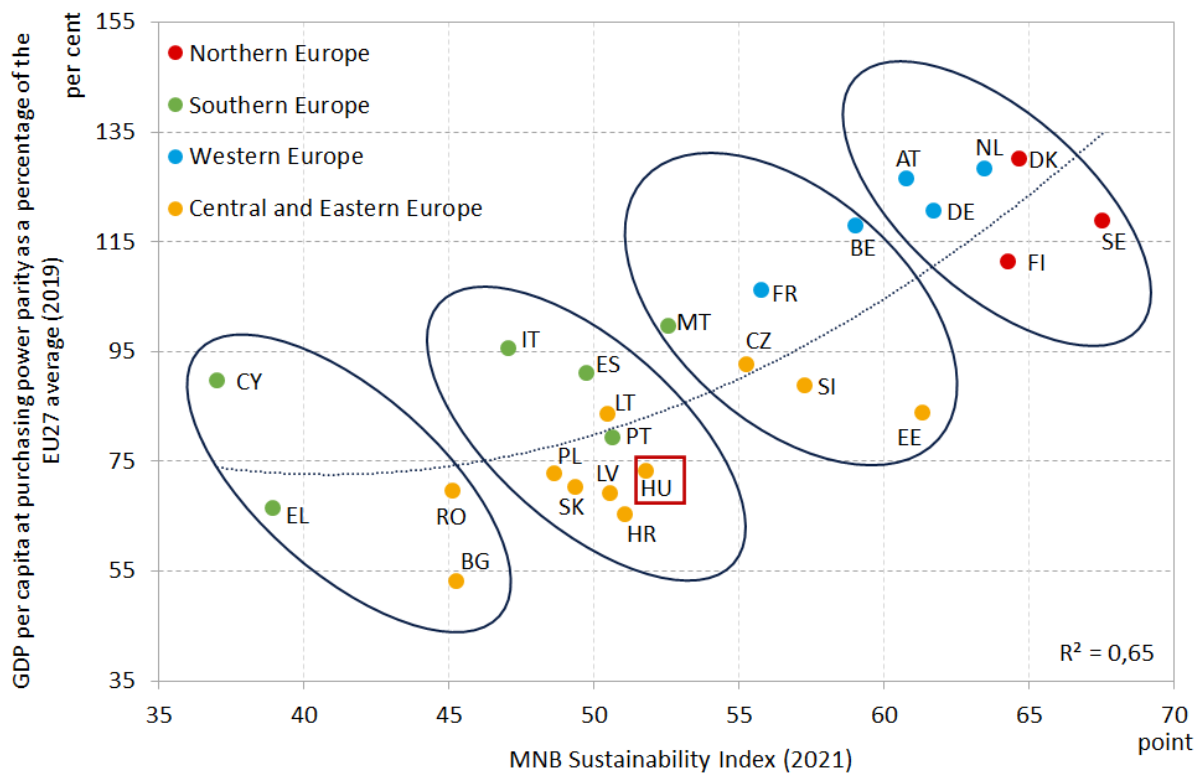

Figure 7. Relationship between the MNB Sustainability Index and economic development (2021). Source: Eurostat and Magyar Nemzeti Bank

Note: In the case of Ireland and Luxemburg, the GDP per capita values are outliers, and thus they are not indicated in the chart.

There is a relatively strong correlation between the relative development of countries and the values of the MNB Sustainability Index (Figure 7). After quantifying the sustainability of EU Member States, our Hypothesis 2, i.e. that there is a correlation between per capita GDP and sustainability, was confirmed. Based on the correlation identified between the relative development indices compared to the EU27 and the MNB Sustainability Index, there are four distinct groups. The leading group includes those developed countries (Sweden, Denmark, Finland, the Netherlands, Germany, Austria) that also outperform other countries in terms of development and sustainability score. In addition to the developed countries 
(Belgium, France, Malta), Estonia, Slovenia and the regional competitor of Hungary the Czech Republic also joined the group of catching-up countries. The group of emerging countries is the largest in number, including Hungary, Slovakia and Poland from the Central European region. Based on its score in the Sustainability Index, Hungary would be able to join the group of catching-up countries, had its relative development level been higher. In order to achieve this, it is important to implement as many of the MNB's recommendations to improve competitiveness as possible. The group of countries lagging behind, comprising Cyprus, Greece, Romania and Bulgaria, is significantly behind Europe both in terms of their relative development and Sustainability Index scores (MNB, 2021).

\section{Conclusions}

According to the MNB Sustainability Report, in addition to real economic factors, the sustainable use of social, financial and environmental resources is a substantial reserve for Hungary's convergence to developed countries and for preserving the social welfare achieved in the long term. The results confirm that there is still room for Hungary to strengthen the transition to a green economy and the digital turnaround. Although Hungary performed above the average in environmental sustainability in the penetration of green finances and the reduction of greenhouse gas emission, an increase in energy efficiency and the more extensive use of environmentally friendly energy resources are essential tasks to complete in order to improve sustainability. The sustainability of economic growth can be improved by making the structure of Hungary's economy more knowledge-intensive and by way of further increasing the productivity of the SME sector, which can be supported by strengthening SMEs' digitalisation and innovation activities. In the area of social sustainability, it is a positive factor that the status of Hungary's public safety is in the vanguard of the EU and the wealth gap is below the average. On the other hand, there is still room for progress in making quality housing more affordable and in increasing the number of people with tertiary education degrees and digital skills. The improvement of the financial dimension of sustainability may be realised through the wider penetration of digital financial services and the reduction of the government debt ratio, among others. On the other hand, in the area of financial sustainability of households, Hungary outperforms its Visegrád competitors and the EU average.

Based on the above, it may be concluded that the MNB Sustainability Report is a unique tool in the domestic economic policy literature as it assesses the sustainability of Hungary and identifies the key areas for strengthening sustainability. On the one hand, the MNB Sustainability Report is in fact an adaptation of the sustainability frameworks proposed by the UN, OECD and other international organisations to Hungarian economic and social conditions along the proposed economic, social and environmental domains. On the other hand, the MNB Sustainability Report can be used for the following purposes: to facilitate strategic and long-term economic and social policy planning, to identify key areas of intervention and to monitor new megatrends resulting from both financial and real economic challenges surfacing in the traditional activities of the central bank and from environmental, social and technological changes (Matolcsy, 2020b). The more extensive use of the MNB Sustainability Report and the Sustainability Index included therein could include the extension of the current geographical focus of the EU to countries around the world or also closer focalisation of OECD or Eurasian countries. A way forward could also entail expanding the set of indicators (currently 4 or 5 indicators belong to each sub-pillar due to size constraints), the addition of new indicators, or the adaptation of old ones for the purpose of measuring new challenges arising from changes in the external environment and in sustainability, while ensuring the continuity of the set of indicators used.

Funding: This research received no external funding.

Conflicts of Interest: The views expressed in this article are those of the authors and do not necessarily reflect the official position of the Magyar Nemzeti Bank. 


\section{References}

1. Asztalos, P., Horváth, G., Krakovsky, S., \& Tóth, T. (2017). Resolving conflicts in measuring the competitiveness of banking systems - the MNB Banking System Competitiveness Index. Hitelintézeti Szemle [Financial and Economic Review], 16(3), 5-31. https://enhitelintezetiszemle.mnb.hu/letoltes/peter-asztalos-gabor-horvath-tefan-krakovsk-tamas-toth.pdf

2. Daly, H. E. (1996). Beyond growth. The Economics of Sustainable Development. Beacon Press, Boston.

3. De Neve, J-E., \& Sachs, J. D. (2020). Sustainable Development and Human Well-Being. In: Helliwell, J. F., Layard, R., Sachs, J. D., \& De Neve, J-E. (Eds.): World Happinness Report 2020. Chapter 6., 113-128. https://worldhappiness.report/ed/2020/sustainabledevelopment-and-human-well-being/\#fn1

4. Dresner, S. (2002). The Principles of Sustainability. Earthscan Publications Limited.

5. Government of Hungary (2013). Act CXXXIX of 2013 on the Magyar Nemzeti Bank. https://net.jogtar.hu/jogszabaly?docid=a1300139.tv

6. Grüll, T. (2013). A Római Birodalom ökológiai hatásai [The ecological impacts of the Roman Empire]. Magyar Tudomány 2013(9), 1026-1034. http://epa.oszk.hu/00600/00691/00120/pdf/EPA00691_mtud_2013_09_1026-1034.pdf

7. Grüll, T. (2017). A Római Birodalom gazdasága [The Economy of the Roman Empire]. Gondolat Kiadó, Budapest. http://real.mtak.hu/74991/1/Grull_nyomdanak.pdf

8. Hardi, P., Barg, S., Hodge, T., \& Pinter, L. (1997). Measuring sustainable development: Review of current practice (Occasional Paper Number 17). International Institute for Sustainable Development - Industry Canada.

9. Hausmann, R. (2021). Tegyük fenntarthatóbbá hazánk növekedési modelljét! [Let's make our country's growth model more sustainable!]. Világgazdaság. https://www.mnb.hu/letoltes/hausmann-robert-tegyuk-fenntarthatobba-hazank-novekedesimodelljet.pdf

10. Jánossy, F. (1966). A Gazdasági fejlödés trendvonala és a helyreállitási periódusok [The trendline of economic growth and restoration periods]. Közgazdasági és Jogi Könyvkiadó, Budapest.

11. Kerekes, S. (1998). A környezetgazdaságtan alapjai [Basics of environmental economics]. Budapest. https://mek.oszk.hu/01400/01452/html/

12. Kopátsy, S. (2000). T.E.T.T. - A minőség társadalma [Nature-Morals-Knowledge-Talent. A society of quality]. Kairosz, Szentendre - Növekedéskutató Intézet, Budapest. https://mek.oszk.hu/02900/02930/html/index.htm

13. Kopátsy, S., \& Bánkuty, T. (2011). Új közgazdaságtan. A minőség társadalma. [New Economics. A Society of Quality]. Akadémiai Kiadó.

14. Lucas Jr., R. E. (1988). On the mechanics of economic development. Journal of Monetary Economics, 22(1), 3-42. https://doi.org/10.1016/0304-3932(88)90168-7

15. Mankiw, G. N., Romer, P. M., \& Weil, D. N. (1992). A Contribution to the Empirics of Economic Growth. The Quarterly Journal of Economics, 107(2), 407-437. https://eml.berkeley.edu/ dromer/papers/MRW_QJE1992.pdf

16. Matolcsy, Gy. (2020a). Egyensúly és növekedés 2010-2019. Sereghajtóból újra éllovas [Economic Balance and Growth, 20102019, From the last to the first]. 2nd Revised Edition Magyar Nemzeti Bank.

17. Matolcsy, Gy. (2020b). Quo vadis Hungaria? - Arccal egy új világ felé [Quo vadis Hungaria? - Facing a New World]. Polgári Szemle [Civic Review Journal of Economic and Social Sciences], 16(1-3); 13-35. https://doi.org/10.24307/psz.2020.1202

18. Meadows, D. H., Meadows, D. L., Randers, J., \& Behrens III, W. W. (1972). The limits to growth. University Books, New York.

19. Mensah, J. (2019). Sustainable development: Meaning, history, principles, pillars, and implications for human action: Literature review. Cogent Social Sciences, 5(1), 1-21. https://doi.org/10.1080/23311886.2019.1653531

20. Mikesell, M. W. (1969). The Deforestation of Mount Lebanon. The Geographical Review, 59(1), 1-28. https://www.jstor.org/stable/213080?seq=1\#metadata info tab contents

21. MNB (2019a). A Magyar Nemzeti Bank jegybanki körökben az elsök között hoz létre elkülönített zöldkötvény-portfóliót a devizatartalékában [Magyar Nemzeti Bank is among the first central banks to create a dedicated green bond portfolio within its foreign exchange reserves]. https://www.mnb.hu/en/pressroom/press-releases/press-releases-2019/magyar-nemzeti-bank-amongthe-first-central-banks-to-create-a-dedicated-green-bond-portfolio-within-foreign-exchange-reserves

22. MNB (2019b). Magyar Nemzeti Bank's (MNB) Green Programme. https://www.mnb.hu/letoltes/mnb-green-program-en.pdf

23. MNB (2020). MNB - Competitiveness Report, 2020. Magyar Nemzeti Bank. https://www.mnb.hu/letoltes/mnb-competitivenessreport-2020-final.pdf

24. MNB (2021). MNB - Sustainability Report, 2021. Magyar Nemzeti Bank. https://www.mnb.hu/letoltes/fenntarthatosagi-jelentes2021-eng-0806.pdf

25. Mohan, A., Thyagarajan, A., \& Muller, N. (2020). Growth, sustainability and the measurement of global gross product. VoxEU-CEPR. https://voxeu.org/article/growth-sustainability-and-measurement-global-gross-product

26. Múlt-kor (2020). Máig szolgálnak megoldatlan rejtélyekkel a Húsvét-sziget óriásszobrai és ökológiai katasztrófája [To this day, the giant Easter Island statues and ecological disaster remain an unsolved mystery]. Múlt-kor. https://mult-kor.hu/maig-szolgalnakmegoldatlan-rejtelyekkela-husvet-sziget-oriasszobrai-es-kologiai-katasztrofaja-20201211

27. Nordhaus, W. D. (1992). The „DICE” Model: Background and Structure of a Dynamic Integrated Climate-Economy Model of the Economics of Global Warming. Cowles Foundation for Research in Economics at Yale University. https://cowles.yale.edu/sites/default/files/files/pub/d10/d1009.pdf

28. Nordhaus, W. D. (2017). Evolution of assessments of the economics of global warming: changes in the DICE model, $1992-2017$. National Bureau of Economic Research Working Paper Series Nr. 23319. https://www.nber.org/system/files/working_papers/w23319/w23319.pdf

29. OECD (2007). Institutionalising Sustainable Development. OECD Sustainable Development Studies. https://doi.org/10.1787/20743262

30. Palotai, D., \& Virág, B. (Eds.) (2016). Versenyképesség és növekedés [Competitiveness and Growth]. Magyar Nemzeti Bank. https://www.mnb.hu/en/publications/mnb-book-series/competitiveness-and-growth

31. Restoy, F. (2020). Central banks and financial stability: A reflection after the Covid-19 outbreak. Financial Stability Institute - Bank for International Settlemenets. OP No. 16. https://www.bis.org/fsi/fsipapers16.pdf 
32. Sachs, J., Schmidt-Traub, G., Kroll, C., Lafortune, G., Fuller, G., \& Woelm, F. (2020). The Sustainable Development Goals and COVID-19. Sustainable Development Report 2020. Cambridge. Cambridge University Press. https://sdgindex.org/reports/sustainable-development-report-2020/

33. Schumpeter, J. A. (1934). The Theory of Economic Development. Harvard Economic Studies 46.

34. SolAbility (2020). The Sustainable Competitiveness Report (9th ed.). SolAbility Sustainable Intelligence. https://solability.com/theglobal-sustainable-competitiveness-index/downloads

35. Spéder, B. (2019). A mérés, mint a problémák alapja [Measurement as the basis of problems]. In: Virág, B. (Eds.): A jövő fenntartható közgazdaságtana [The sustainable economics of the future]. 31-51. https://www.mnb.hu/en/publications/mnb-book-series/longterm-sustainable-econo-mix

36. TH Köln (2018). Sustainable Society Index 2018. Technische Hochschule Köln. https://ssi.wi.th-koeln.de/documents/SSI-2018scores.pdf

37. United Nations (1987). Report of the World Commission on Environment and Development: Our Common Future. https://sustainabledevelopment.un.org/content/documents/5987our-common-future.pdf

38. United Nations (1992). Agenda 21. United Nations Conference on Environment \& Development, Rio de Janeiro, Brazil, 3 to 14 June 1992. https://sustainabledevelopment.un.org/outcomedocuments/agenda21

39. United Nations (2000). United Nations Millenium Declaration (A/55/L.2) https://undocs.org/A/RES/55/2

40. United Nations (2012). The future we want https://www.un.org/ga/search/view_doc.asp?symbol=A/RES/66/288\&Lang=E

41. United Nations (2019). Planetary pressures-adjusted Human Development Index (PHDI). United Nations Development Programme. http://hdr.undp.org/sites/default/files/2020 phdi.pdf

42. Virág, B. (Eds.). (2019). A jövő fenntartható közgazdaságtana [The sustainable economics of the future]. Magyar Nemzeti Bank. https://www.mnb.hu/en/publications/mnb-book-series/long-term-sustainable-econo-mix 


\section{Appendix}

Appendix 1. Results of the MNB Sustainability Index by sub-pillars (2021)

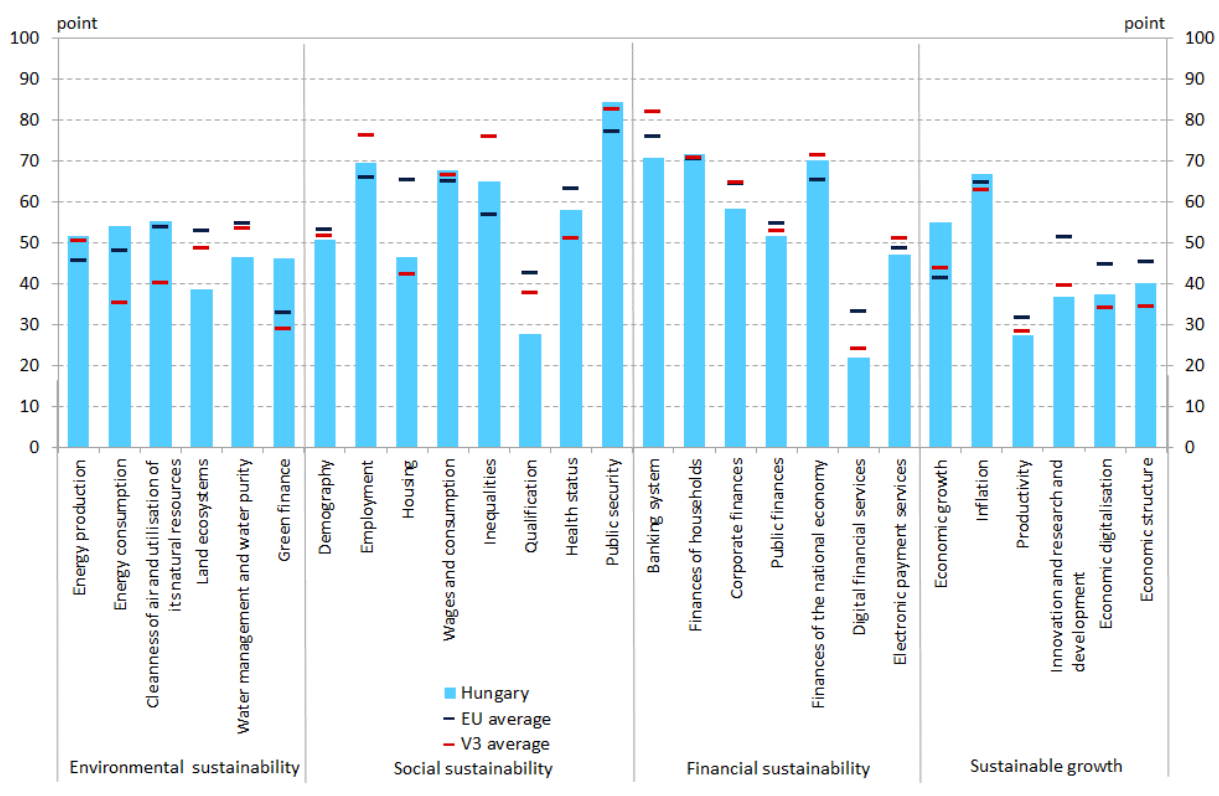

Source: Magyar Nemzeti Bank

Note: The scale ranges from 0 to 100 points, with 100 being the best value. 